\title{
Proctolin Activates an Inward Current Whose Voltage Dependence Is Modified by Extracellular $\mathrm{Ca}^{2+}$
}

\author{
Jorge Golowasch ${ }^{\mathrm{a}}$ and Eve Marder \\ Biology Department, Brandeis University, Waltham, Massachusetts 02254
}

The pentapeptide proctolin modulates the activity of the rhythmic pattern generators in the crustacean stomatogastric nervous system. Proctolin strongly excites the lateral pyloric and the inferior cardiac neurons of the stomatogastric ganglion (STG), causing them to fire extended high-frequency bursts of action potentials (Hooper and Marder, 1987; Nusbaum and Marder, $1989 a, b)$. We now report that proctolin depolarizes these cells maximally at membrane potentials close to the threshold for action potential generation. In voltage clamp, proctolin evokes an inward current, carried at least partially by $\mathrm{Na}^{+}$, that shows strong outward rectification. Removal of extracellular $\mathrm{Ca}^{2+}$ markedly increases the amplitude of the proctolin-evoked current and linearizes its current-voltage curve. The properties of the proctolin current make it ideally suited to contribute to the activity-dependent modulation of the pyloric network of the STG.

The stomatogastric ganglion (STG) of decapod crustaceans contains the networks that generate several different rhythmic motor patterns (Selverston and Moulins, 1987). These rhythmic motor patterns are modulated by a number of different substances (Marder, 1984, 1987; Flamm and Harris-Warrick, 1986; Hooper and Marder, 1987; Heinzel and Selverston, 1988; Nusbaum and Marder, 1989a,b), but the cellular mechanisms underlying their actions are largely unknown.

Among the substances that modulate the pyloric rhythm of the STG is the pentapeptide proctolin (Arg-Tyr-Leu-Pro-Thr$\mathrm{NH}_{2}$ ). Proctolin is found in the stomatogastric system (Marder et al., 1986) and is contained in two identified cells located in an adjacent ganglion that project into the STG (Nusbaum and Marder, 1989a,b). The actions of the proctolin-containing neurons are well mimicked by exogenously applied proctolin (Hooper and Marder, 1987; Nusbaum and Marder, 1989b). Nusbaum and Marder (1989b) showed that the effect of proctolin on the pyloric rhythm depends on the state of the network (as monitored by the frequency of the pyloric rhythm) prior to proctolin application. Specifically, if the rhythm is active, proctolin has little or no effect, but when the rhythm is slow or absent, proctolin strongly excites it (Nusbaum and Marder, 1989b).

\footnotetext{
Received Aug. 27, 1991; accepted Oct. 10, 1991.

We thank Drs. Jacsue Kehoe, Pierre Meyrand, and Ronald Calabrese for helpful comments on previous versions of the manuscript. This research was supported by National Institutes of Health Grant NS 17813 .

Correspondence should be addressed to Dr. Eve Marder, Biology Department, Brandeis University, Waltham, MA 02254.

a Present address: Laboratoire de Neurobiologie, École Normale Supérièure, 46 rue d'Ulm, 75005, Paris, France.
}

Copyright (C) 1992 Society for Neuroscience $0270-6474 / 92 / 120810-08 \$ 05.00 / 0$
Hooper and Marder (1987) showed that proctolin's action on the pyloric network results from the activation of only a few target cells. One of our eventual aims is to understand the cellular mechanisms that underlie the modulation of the motor patterns produced by the STG. To this end, it is important to characterize the properties of the currents either modulated by proctolin or evoked by proctolin in its target neurons. We now present evidence that the action of proctolin on the lateral pyloric (LP) and inferior cardiac (IC) neurons can be explained by its activation of a small inward current that shows strong outward rectification, is reduced by extracellular $\mathrm{Ca}^{2+}$, and, in normal saline, is maximal close to the threshold for action potential generation.

\section{Materials and Methods}

STG from crabs, Cancer borealis, were dissected as customary (Selverston and Moulins, 1987). The data in this article come from more than 70 experiments. The animals were kept in seawater aquaria at $12-15^{\circ} \mathrm{C}$ and the experiments were performed at $9-11^{\circ} \mathrm{C}$. STG were pinned into Sylgard-lined Petri dishes and desheathed. Cells were identified as described in Hooper et al. (1986). The STG were surrounded by a small plastic chamber $(\mathrm{vol} \approx 300 \mu \mathrm{l})$ to allow fast changes of the STG solution (nerves and other adjacent ganglia remain in normal saline) and superfused constantly with saline through a cooling device using thermoelectric heat pumps (Melcor, Trenton, NJ) at a rate of $7-8 \mathrm{ml} / \mathrm{min}$.

Action potential inputs from anterior ganglia were blocked with isotonic sucrose (750 $\mathrm{mm}$ ) around the stomatogastric nerve (stn). The composition of Cancer saline (in $\mathrm{mM}$ ) was $440 \mathrm{NaCl}, 11 \mathrm{KCl}, 13 \mathrm{CaCl}_{2}$, $26 \mathrm{MgCl}_{2}, 5$ maleic acid, and 11 Trizma base, $\mathrm{pH}$ 7.4-7.5. All experiments were performed on LP or IC cells impaled with two micropipettes filled with either $0.6 \mathrm{M} \mathrm{K}_{2} \mathrm{SO}_{4}$ plus $20 \mathrm{mM} \mathrm{KCl}$ (10-25 $\mathrm{M} \Omega$ resistance) or $2.5 \mathrm{M} \mathrm{KCl}(5-15 \mathrm{M} \Omega$ resistance). About $90 \%$ of the cells we studied were LP cells, and the remaining were IC cells. All the results here described were found for both cell types.

An Axoclamp 2A (Axon Instruments, Foster City, CA) was used for two-electrode current clamp (2ECC) or two-electrode voltage clamp (TEVC). The voltage clamp was driven with, and the currents and voltages were recorded, stored, and subsequently analyzed on, a computer with the pCLAMP software (version 5.5, Axon Instruments). Voltages and currents were also recorded on line on a Gould 2400 chart recorder (Gould Inc., Cleveland, OH). For TEVC, the gain was set to the instrument's maximum $\left(10,000 V_{\text {output }} / V_{\text {error }}\right.$; see Axoclamp $2 \mathrm{~A}$ manual), and capacitance compensation was used. The ground was a calomel reference electrode connected to the bath through an agar bridge (4\% agar in $0.6 \mathrm{M} \mathrm{K}_{2} \mathrm{SO}_{4}+20 \mathrm{mM} \mathrm{KCl}$ ). At the end of each experiment, we checked the electrode offset and discarded the results if it exceeded $\pm 5 \mathrm{mV}$.

The cells were pharmacologically isolated (Golowasch, 1990) by first placing the ganglion in $10 \mu \mathrm{M}$ picrotoxin (PTX; Sigma) and $1 \mu \mathrm{M}$ TTX (Calbiochem) for $10 \mathrm{~min}$. Subsequently, the saline contained $10 \mu \mathrm{M}$ PTX and $0.1 \mu \mathrm{M}$ TTX (see Fig. 1). Because all the pyloric neurons are normally active in normal saline (i.e., firing tonically or bursting), we defined the resting potential $\left(V_{\text {ress }}\right)$ of the cell as the membrane potential seen in PTX + TTX, which blocks bursting, action potential generation and synaptic activity. All TEVC recordings were performed in the presence of $10 \mu \mathrm{M}$ PTX, $0.1 \mu \mathrm{M}$ TTX, $10 \mathrm{~mm}$ tetraethylammonium (TEA; 

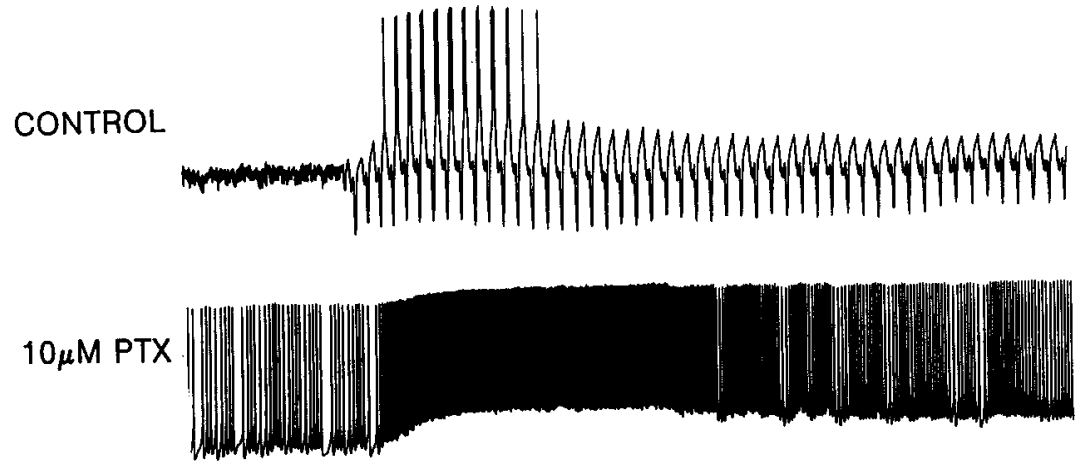

Figure 1. Proctolin response of an LP neuron at different levels of pharmacological isolation. Conduction along the stn input nerve was blocked. Proctolin $(P R O C)$ puffs were applied $(0.5$ $\mathrm{sec})$ at the time shown by the horizontal bar. Top trace, normal saline; baseline membrane potential, $-48 \mathrm{mV}$. Middle trace, after $30 \mathrm{~min}$ in PTX; baseline membrane potential, $-38 \mathrm{mV}$. Bottom trace, $10 \mu \mathrm{M}$ PTX + $0.1 \mu \mathrm{M}$ TTX; base$10 \mu \mathrm{M}$ PTX $0.1 \mu \mathrm{M}$ TTX $\int_{5 \mathrm{~s}} 5 \mathrm{mV}$ line membrane potential, $-38 \mathrm{mV}$.

Sigma), and $200 \mu \mathrm{M} \mathrm{Cd} \mathrm{Cd}^{2+}$ to block the inhibitory synaptic potentials, the fast inward current underlying action potential generation, most of the outward currents (delayed rectifier and $\mathrm{Ca}^{2+}$-activated outward current), and the $\mathrm{Ca}^{2+}$ currents expressed by these cells, respectively (Golowasch, 1990). When $\mathrm{Ca}^{2+}$ was removed, $0.1 \mathrm{mM} \mathrm{Ca}^{2+}$ was retained to ensure cell survival. For $\mathrm{Na}^{+}$concentration changes, we used $\mathrm{N}$-methyl-D-glucamine (NMDG; Sigma; $\mathrm{pH}$ adjusted with $\mathrm{HCl}$ ) or Tris to replace $\mathrm{Na}^{+}$.

Proctolin (Sigma) was dissolved in $\mathrm{H}_{2} \mathrm{O}$, and aliquots of $10^{-2} \mathrm{M}$ were kept frozen at $-20^{\circ} \mathrm{C}$. Proctolin was applied by pressure using a Picospritzer II (General Value Corp., Fairfield, NJ) from a pipette filled with a $10^{4} \mathrm{M}$ solution prepared in either normal saline or the same solution as the bath. No difference was observed between these solutions. The proctolin pipette was moved around over the neuropil area to find the position that elicited the maximal response. One or two responsive spots were typically found in each ganglion. No somatic responses were obtained. Proctolin puffs were typically applied at 4-5 min intervals to allow for full recovery of the response. Normally, this protocol allowed for several hours of work with no deterioration of the responses.

\section{Results}

When activity in the nerve connecting the STG to more anterior ganglia (stn) is blocked, the pyloric rhythm often stops. However, if a puff of proctolin is delivered, a short period of pyloric rhythm activity is elicited, as seen in the intracellular recording from the LP neuron shown in Figure 1 (top trace). Note that the LP neuron slowly depolarized, fired bursts of action potentials intcruptcd by synaptic inhibition from other pyloric neurons, and then slowly repolarized. The large IPSPs seen in the top trace of Figure 1 can be blocked by placing the preparation in PTX. Under these conditions, a proctolin puff still elicits a long-lasting depolarization with much the same time course and amplitude as that seen in control saline (Fig. 1, second trace). To isolate further the neuron from presynaptic inputs and to achieve better voltage control, the preparations were placed in TTX. The bottom trace of Figure 1 shows that the proctolin response in TTX maintains the same essential form and amplitude of that in control saline.

The amplitude of the proctolin response varied as a function of membrane potential $\left(V_{m}\right)$. Figure $2 A$ shows the response of an LP neuron to puffs of proctolin recorded in $2 \mathrm{ECC}$ from a baseline of three different membrane potentials. The response is largest at $V_{m}=-60 \mathrm{mV}$ and becomes smaller as the cell is either depolarized or hyperpolarized. Figure $2 B$ shows the peak responses of the same cell as a function of the baseline $V_{m}$. The maximum response occurs almost exactly at $V_{\text {rest }}$ (see definition in Materials and Methods) of the cell. In current clamp, it was not possible to measure a reversal potential $\left(F_{\mathrm{rcr}}\right)$ since we were unable to hold the cells at voltages more depolarized than around $-20 \mathrm{mV}$ or more hyperpolarized than around $-90 \mathrm{mV}$ for extended times. Notice, however, the apparent voltage dependence of the response and an apparent extrapolated $E_{\text {rev }}$ of around $0 \mathrm{mV}$.

To characterize more accurately the dependence of the proctolin response on voltage, we placed the LP or IC neurons in TEVC and used several different paradigms to describe the proctolin response. To generate the current-voltage relationship for the proctolin current shown in Figure 3 (as well as Figs. $4 B$, $5 B)$, the membrane potential was held $\left(V_{h}\right)$ at $-40 \mathrm{mV}$, and test pulses $\left(V_{\text {test }}\right)$ to various potentials were applied. The same pulse paradigm was repeated in control saline, and in the presence of proctolin. The proctolin-induced current was calculated as the difference between the control and proctolin measurements. Figure $3 A$ shows the superimposed current traces obtained from $V_{h}=-40 \mathrm{mV}$ to a $V_{\text {test }}=-50 \mathrm{mV}$ in the absence (CTRL) and in the presence of proctolin (PROC). As can be observed in this example, and was found to be the case at all voltages tested, the rate of activation was relatively fast (faster than the approximately $25 \mathrm{msec}$ that the uncompensated capacitance artifact lasts), and no time-dependent changes in the current were detected either during the $500 \mathrm{msec}$ pulse or following the return to the holding potential (Fig. $3 A$ ). Figure $3 B$ shows the $I / V$ curve of the net proctolin-evoked current (control subtracted) measured at the end of the $500 \mathrm{msec}$ test pulse. This again shows the strong voltage dependence of the proctolin-evoked current, with a clear outward rectification and an $E_{\text {rev }}$ of around -10 $\mathrm{mV}$ in this cell.

Table 1 shows the values of $V_{\text {rest }}$, the voltage of the peak proctolin response, and the action potential threshold measured for $67 \mathrm{LP}$ neurons recorded either with $\mathrm{K}_{2} \mathrm{SO}_{4}$ or $\mathrm{KCl}$ electrodes. Note that the potential of the peak proctolin current and the resting potential were within a millivolt of each other but that the recording electrolyte influenced the absolute values of these measurements. Measurements obtained with $\mathrm{KCl}$-filled electrodes were significantly more positive than those obtained with $\mathrm{K}_{2} \mathrm{SO}_{4}$ electrodes, which suggests an influence of intracellular $\left[\mathrm{Cl}^{-}\right]$on both the $V_{\text {rest }}$ and the proctolin-evoked conductance. We attempted to determine the ions carrying the proctolin current 
A

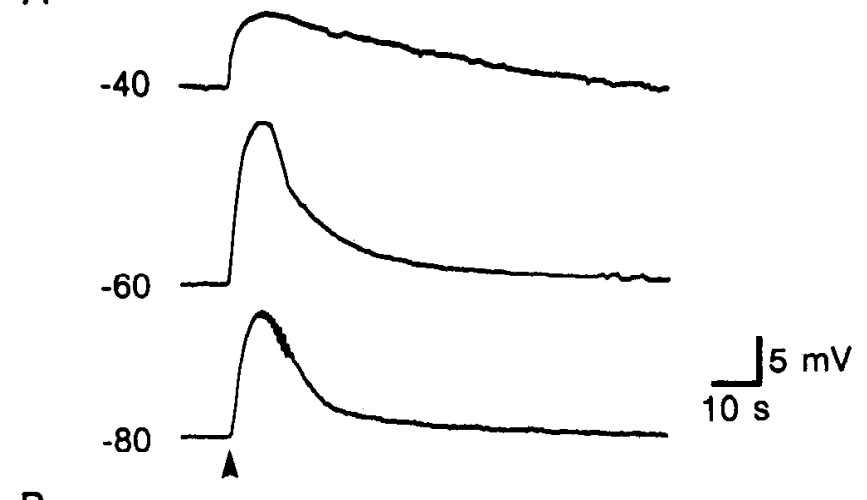

B

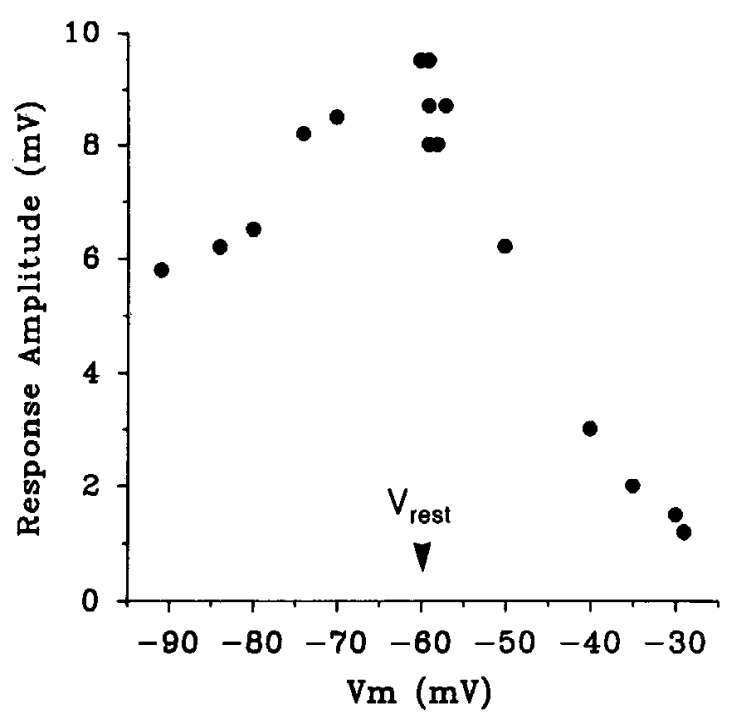

Figure 2. The response of the LP neuron to proctolin at different membrane potentials. Proctolin $(100 \mu \mathrm{M})$ was pressure applied $(1.5 \mathrm{sec}$ pulse at the arrowhead) over the neuropil of a ganglion bathed in 10 $\mu \mathrm{M}$ PTX and $0.1 \mu \mathrm{M}$ TTX. Two $\mathrm{K}_{2} \mathrm{SO}_{4}$ electrodes were placed in the cell. $A$, Responses obtained at the membrane potentials indicated (in $\mathrm{mV}$ ) to the left of the traces. $B$, Peak amplitude of the responses of the cell in $A$ (measured from the baseline) as a function of the baseline $V_{m}$. The $V_{\text {rest }}$ of this particular cell is indicated by the arrowhead.

by measuring the effects of changing the composition of the extracellular fluid on $E_{\text {rev }}$. However, our ability to measure $E_{\text {rev }}$ accurately was hindered by the large amplitude of the leak current, the outward currents that activate at depolarized membrane potentials (Golowasch, 1990), and the neuropilar location of the proctolin receptors, which results in a somewhat compromised space clamp in the depolarized range of membrane potentials where the response reverses. However, in control saline, $E_{\mathrm{rev}}$ of the proctolin response was $-2.9 \pm 14.7 \mathrm{mV}$ ( $n$ =17).

A decrease in the amplitude of the proctolin-evoked current (Fig. $4 A$ ) and a clear shift of the $I / V$ curve to more hyperpolarized values was seen when the extracellular $\mathrm{Na}^{+}$concentration was decreased to one-half of control values (Fig. 4B). Additionally, a total block of the response was seen when all the extracellular $\mathrm{Na}^{+}$was replaced with either Tris or NMDG (not shown). In six cells, we were able to measure the proctolinevoked current's $E_{\text {rev }}$ in normal $\left[\mathrm{Na}^{+}\right]_{\text {out }}$ and in $50 \%\left[\mathrm{Na}^{+}\right]_{\text {out }}$. In these cells, $E_{\mathrm{rev}}$ in control saline was $-0.8 \pm 13.7 \mathrm{mV}$ and $E_{\mathrm{rev}}$ in $50 \%\left[\mathrm{Na}^{+}\right]_{\text {out }}$ was $-11.0 \pm 9.2 \mathrm{mV}$ (these values differ sig-
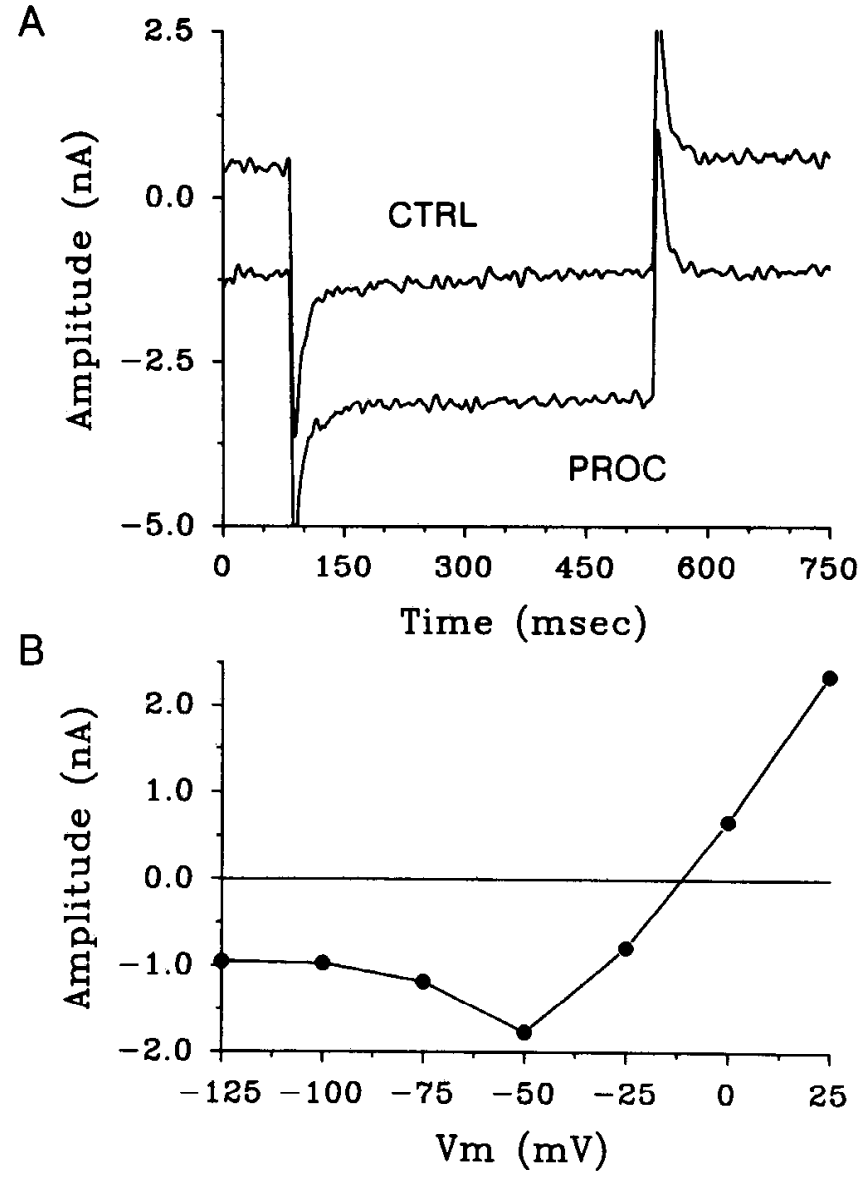

Figure 3. Voltage dependence of the proctolin current. The cell was impaled with two $\mathrm{K}_{2} \mathrm{SO}_{4}$ electrodes, and currents were recorded in the presence of $10 \mu \mathrm{M}$ PTX, $0.1 \mu \mathrm{M}$ TTX, $10 \mathrm{mM}$ TEA, and $200 \mu \mathrm{M} \mathrm{Cd}^{2+}$. Currents were digitally filtered at $1 \mathrm{kHz}$. $A$, Raw currents obtained with a pulse from a $V_{h}=-40 \mathrm{mV}$ to a $V_{\text {test }}=-50 \mathrm{mV}$ in control saline (CTRL) and during the peak response to a puff of proctolin (PROC). $B$, Net proctolin evoked currents ( $P R O C$ minus $C T R L)$ measured in the same cell at the end of the 500 msec pulses, as a function of the test potential.

nificantly, $p<0.05$ ). In contrast, extracellular $\mathrm{K}^{+}$concentration changes had no apparent effect on the reversal potential of the proctolin response. In current clamp, the response to proctolin at $V_{\text {rest }}$ would be expected to decrease in amplitude as $E_{\mathrm{K}}$ is madc more negative if the proctolin current was carried partially by $\mathrm{K}^{+}$. Figure $5 A$ shows that even a 10 -fold decrease in $\left[\mathrm{K}^{+}\right]_{\text {out }}$ did not produce a decrease in the response's amplitude. Figure $5 B$ shows in TEVC that neither the proctolin-evoked current's amplitude nor the $I / V$ relationship was appreciably affected by changes in extracellular $\mathrm{K}^{+}$. This result was observed in four different cells. Extracellular $\mathrm{Cl}^{-}$concentration changes showed inconsistent results, due probably to a high resting $\mathrm{Cl}^{-}$conductance of these cells (Marder and Paupardin-Tritsch, 1978). In general, $\mathrm{Cl}^{-}$replacement with methyl sulfate or isethionate had no effect on the proctolin current. However, as mentioned before, both $V_{\text {rest }}$ and the voltage at which the peak proctolin response occurs are about $10 \mathrm{mV}$ more depolarized when these parameters are measured with $\mathrm{KCl}$ - instead of $\mathrm{K}_{2} \mathrm{SO}_{4}$-filled electrodes (Table 1). This may suggest a partial contribution of $\mathrm{Cl}^{-}$ to the proctolin current. Together, these data lead us to conclude that the proctolin-evoked current is mainly carried by $\mathrm{Na}^{+}$. 
A

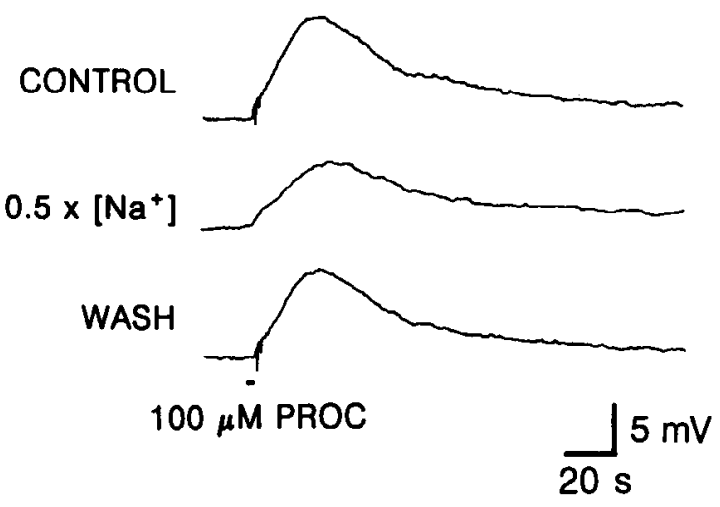

B

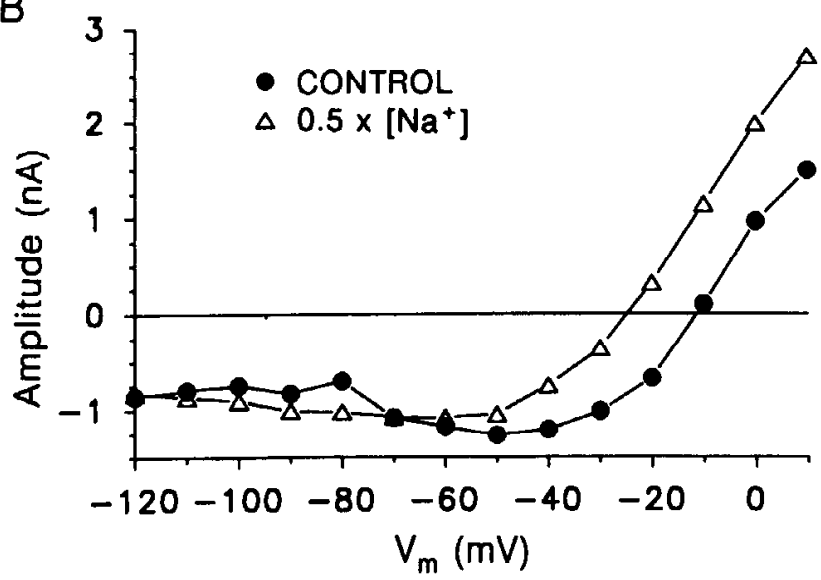

Figure 4. Effect of extracellular $\mathrm{Na}^{+}$concentration: cell in $10 \mu \mathrm{M}$ PTX $+0.1 \mu \mathrm{M}$ TTX. $A, 2 \mathrm{ECC}$ recordings in normal $\left[\mathrm{Na}^{+}\right](C O N T R O L$ and $W A S H)$ and in $50 \%\left[\mathrm{Na}^{+}\right]$, replaced with NMDG. The $\left[\mathrm{Ca}^{2+}\right]_{\text {ou }}$ was decreased to $1 \mathrm{~mm}$ to enhance the amplitude of the response. Note the decrease in amplitude of the response in low $\left[\mathrm{Na}^{+}\right]$. The horizontal bar under the bottom trace indicates the time and duration $(2 \mathrm{sec})$ of the proctolin (PROC) puff. $B$, Different LP cell in TEVC impaled with two $5 \mathrm{M} \mathrm{CsCl}$ electrodes to block outward $\mathrm{K}^{+}$currents. $V_{h}=-40 \mathrm{mV}$. CONTROL, normal $\left[\mathrm{Na}^{+}\right] . \mathrm{Na}^{+}$was also replaced with NMDG. The $E_{\text {rev }}$ shift was $-13 \mathrm{mV}$.

However, the imprecision in measuring $E_{\mathrm{rev}}$ mentioned above makes it virtually impossible to measure small shifts in $E_{\mathrm{rev}}$, thus impeding us from demonstrating the contribution of other ions to the proctolin current. In fact, the relatively low estimated $E_{\text {rev }}$ suggests that this is a mixed cation current, as has been shown for a number of other preparations expressing a current with similar properties (Aldenhoff et al., 1983; Kononenko et al., 1983; Haynes et al., 1986; Nakamura and Gold, 1987; Kehoe, 1990), with perhaps a small $\mathrm{Cl}^{-}$contribution.
A

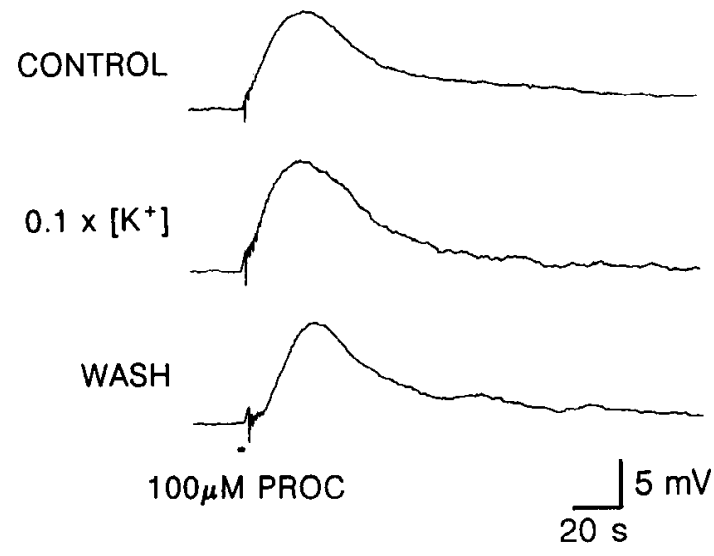

B

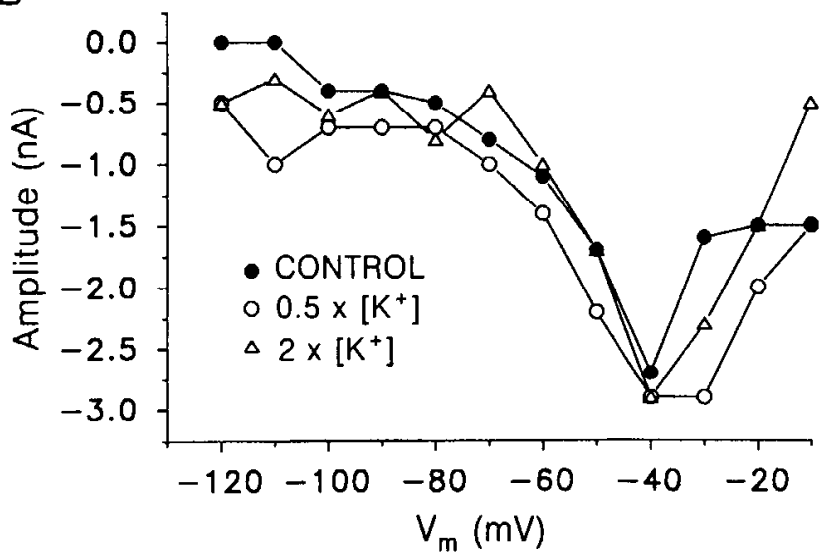

Figure 5. Effect of extracellular $\mathrm{K}^{+}$concentration: preparation in 10 $\mu_{\mathrm{M}} \mathrm{PTX}+0.1 \mu \mathrm{M}$ TTX. $A$, Same cell and conditions as in Figure $4 A$. The extracellular $\left[\mathrm{K}^{+}\right]$was changed without compensation $\left(0.1 \times\left[\mathrm{K}^{+}\right]\right.$ $=1.1 \mathrm{mM}$ ). Note that the proctolin response does not decrease in amplitude. $B, \mathrm{IC}$ cell in TEVC, impaled with $\mathrm{K}_{2} \mathrm{SO}_{4}$ electrodes. $V_{h}=-60$ $\mathrm{mV}$. Here also the extracellular $\left[\mathrm{K}^{+}\right]$was changed without compensation.

Figure 6 shows the effects of divalent cations on the proctolinevoked current. The concentration of divalent cations in the bath was kept constant and equal to the sum of the $\mathrm{Ca}^{2+}$ and $\mathrm{Mg}^{2+}\left(\left[\mathrm{Ca}^{2+}\right]_{\text {out }}\right.$ and $\left[\mathrm{Mg}^{2+}\right]_{\text {out }}$, respectively) concentrations in normal saline (i.e., $39 \mathrm{~mm}$ ), with $0.1 \mathrm{mM} \mathrm{Ca}^{2+}$ always present to avoid cell deterioration. An enhanced response was seen only when $\mathrm{Mg}^{2+}$ was the sole divalent cation present. All the other divalent cations tested caused a diminution in the response. $\mathrm{Ba}^{2+}$ and $\mathrm{Co}^{2+}$ had the strongest blocking effect, and their action was less reversiblc than that of $\mathrm{Mn}^{2+}$ and $\mathrm{Ca}^{2+}$. We were unable

Table 1. Effect of recording electrolyte on $V_{\text {ress }} V_{\text {peak }}$ proc, and $V_{\text {threshold }}$

\begin{tabular}{llll} 
& $V_{\text {rest }}(\mathrm{mV})$ & $V_{\text {peak }}$ proc $(\mathrm{mV})$ & $V_{\text {threshoid }}(\mathrm{mV})$ \\
\hline $\mathrm{K}_{2} \mathrm{SO}_{4}$ electrodes & $-52.0 \pm 7.4^{* *}$ & $-52.2 \pm 11.7^{*}$ & $-45.8 \pm 4.4^{* *}$ \\
& $n=42$ & $n=10$ & $n=15$ \\
$\mathrm{KCl}$ electrodes & $-43.6 \pm 5.8^{* *}$ & $-43.1 \pm 7.2^{*}$ & $-39.1 \pm 2.9^{* *}$ \\
& $n=25$ & $n=16$ & $n=12$
\end{tabular}

$V_{\text {eak }}$ proc is the membrane potential of the peak proctolin-evoked response. $V_{\text {theshold }}$ is the membrane potential at which action potentials were first elicited.

${ }^{* *}, p<0.001 ; *, p<0.01$ : Student's $t$ test applied between values recorded with different electrolytes. All are tests for independent means. 
CONTROL
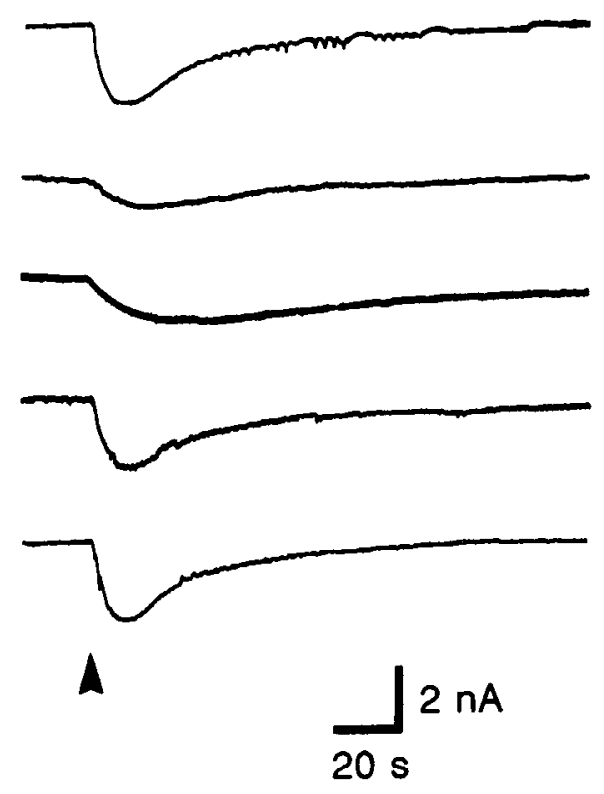

TEST
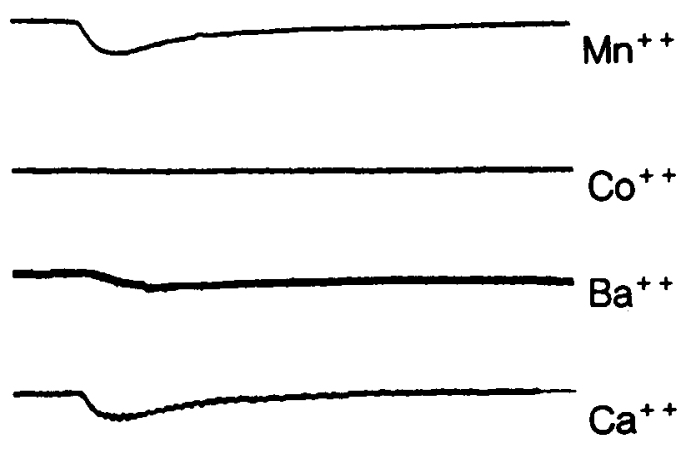

arrowheads, cells were impaled with electrodes and maintained at $V_{h}=-40$ $\mathrm{mV}$. The control solution was normal saline plus PTX, TTX, TEA, and $\mathrm{Cd}^{2+}$. The test solutions were control saline containing $0.1 \mathrm{mM} \mathrm{Ca}^{2+}+38.9 \mathrm{~mm}$ of another divalent cation (indicated to the right of each trace), thus maintaining the total divalent cation concentration constant and equal to that of normal saline. The left-hand traces were "control saline" and the right-hand traces were "test salines." Records come from two different cells.

Figure 6. Effect of divalent cation concentrations on the proctolin-evoked current. Proctolin puffs were given at

to use $\mathrm{Cd}^{2+}$ at high concentrations because of its toxic effects, although $200 \mu \mathrm{M} \mathrm{Cd}{ }^{2+}$ was always present in the solution in order to block $\mathrm{Ca}^{2+}$ and, indirectly, $\mathrm{Ca}^{2+}$-activated currents. The blocking effect of the high $\mathrm{Ca}^{2+}$ (threefold the normal concentration; Fig. 6, trace 4) and the enhancing effect of the high$\mathrm{Mg}^{2+} / \mathrm{low}-\mathrm{Ca}^{2+}$ solution (bottom trace) suggest that the proctolin-evoked current is blocked by divalent cations other than $\mathrm{Mg}^{2+}$, including $\mathrm{Ca}^{2+}$. The question remains whether it is the low $\left[\mathrm{Ca}^{2+}\right]_{\text {out }}$ or the high $\left[\mathrm{Mg}^{2+}\right]_{\text {out }}$ in the high- $\mathrm{Mg}^{2+} / \mathrm{low}-\mathrm{Ca}^{2+}$ solution that accounts for the enhancement of the proctolin current seen in the bottom trace of Figure 6.

Figure 7 shows the effects of $\left[\mathrm{Ca}^{2+}\right]_{\text {out }}$ changes with and without compensation with $\mathrm{MgCl}_{2}$. Figure $7 A$ demonstrates that the amplitude enhancement of the current is independent of $\left[\mathrm{Mg}^{2+}\right]_{\text {out }}$ and is only a function of $\left[\mathrm{Ca}^{2+}\right]_{\text {our }}$. The $l / \mathrm{V}$ curves shown in Figure 7, $B$ and $C$, differ in that in Figure $7 B$ no $\mathrm{Mg}^{2+}$ compensation was used for the decreased cxtracellular $\mathrm{Ca}^{2+}$ while in Figure $7 C$ the total divalent cation concentration was kept constant with the addition of $\mathrm{MgCl}_{2}$. Here we observe that the amplitude of the proctolin-evoked current increased as $\left[\mathrm{Ca}^{2+}\right]_{\text {out }}$ was decreased, regardless of whether the divalent cation concentration was kept constant, suggesting that this increase was due to the removal of a block of the proctolin current by extracellular $\mathrm{Ca}^{2+}$. In addition, the outward rectification of the current seen in normal divalent cation conditions $\left(13 \mathrm{mM} \mathrm{Ca}^{2+}\right.$ / $26 \mathrm{mM} \mathrm{Mg}^{2+}$ ) progressively decreased as $\left[\mathrm{Ca}^{2+}\right]_{\text {out }}$ was lowered. The linearization of the $I / V$ curve was not complete even at the lowest $\left[\mathrm{Ca}^{2+}\right]_{\text {out }}$, however (i.e., $0.1 \mathrm{mM} \mathrm{Ca}^{2+}$ and no $\mathrm{Mg}^{2+}$ compensation; Fig. $7 B$ ), perhaps because of a block by the residual $\mathrm{Ca}^{2+}$. The results shown in Figures 6 and 7 are characteristic of recordings repeated in six cells.

\section{Discussion}

It is interesting that extracellular $\mathrm{Ca}^{2+}$ decreases the amplitude of the proctolin-evoked inward current at all membrane potentials, but most markedly at hyperpolarized membrane poten- tials. At the very high ionic strength of the normal crab saline, it is unlikely that a surface charge effect can account for these results. Removal of extracellular $\mathrm{Ca}^{2+}$ has the same effect on the current-voltage relationship of this current with or without compensation with $\mathrm{Mg}^{2+}$, namely, to linearize the strong rectification of the current at negative potentials. Similar, albeit less dramatic, effects of divalent cations have been described for cyclic nucleotide-activated cationic currents of a number of preparations (Haynes et al., 1986; Gillette and Green, 1987; Nakamura and Gold, 1987). Our results are also strongly reminiscent of the blocking effect by $\mathrm{Mg}^{2+}$ on the NMDA-activated current (Nowak et al., 1984). This argues that extracellular $\mathrm{Ca}^{2+}$ ions actually block the channels underlying the proctolin-evoked current. These effects of extracellular $\mathrm{Ca}^{2+}$ may play an important physiological role in crustaceans since large changes (between $10 \%$ and $100 \%$ ) of $\mathrm{Ca}^{2+}$ concentration in the hemolymph may occur during molting (Greenaway, 1985).

We suggest that $\mathrm{Na}^{+}$is the major ion carrying the proctolinevoked current. Extracellular $\mathrm{Na}^{+}$concentration changes displace the $I / V$ curve of the proctolin current, and other ions fail to affect the $I / V$ curve in a manner expected for major charge carriers of this current. However, the low reversal potentials we measure suggest that $\mathrm{Cl}^{-}$or $\mathrm{K}^{+}$also contributes to this current. The proctolin response that we describe here is similar to that reported by Freschi (1989) in lobster cardiac ganglion neurons except that the peak inward current reported by Freschi (1989) is seen at more depolarized voltages (at about $-20 \mathrm{mV}$ in contrast with our result of about $-43 \mathrm{mV}$ with $\mathrm{KCl}$ electrodes). It would be interesting to determine whether this difference is an intrinsic difference in the voltage dependence of the proctolinactivated channels in the two preparations, or whether it is somehow a consequence of different divalent concentrations in the salines used in the two studies (our control saline is $13 \mathrm{~mm}$ $\mathrm{Ca}^{2+}, 26 \mathrm{mM} \mathrm{Mg}^{2+}$, whereas that used by Freschi was $25 \mathrm{~mm}$ $\mathrm{Ca}^{2+}, 8 \mathrm{mM} \mathrm{Mg}^{2+}$ ).

In a number of other preparations, currents with voltage de- 
A

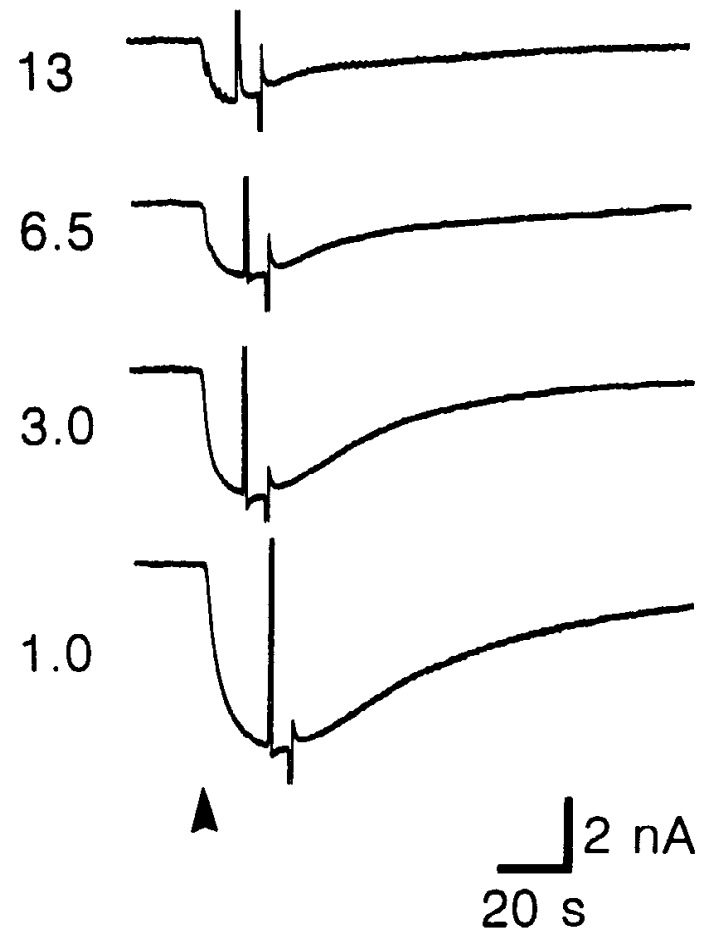

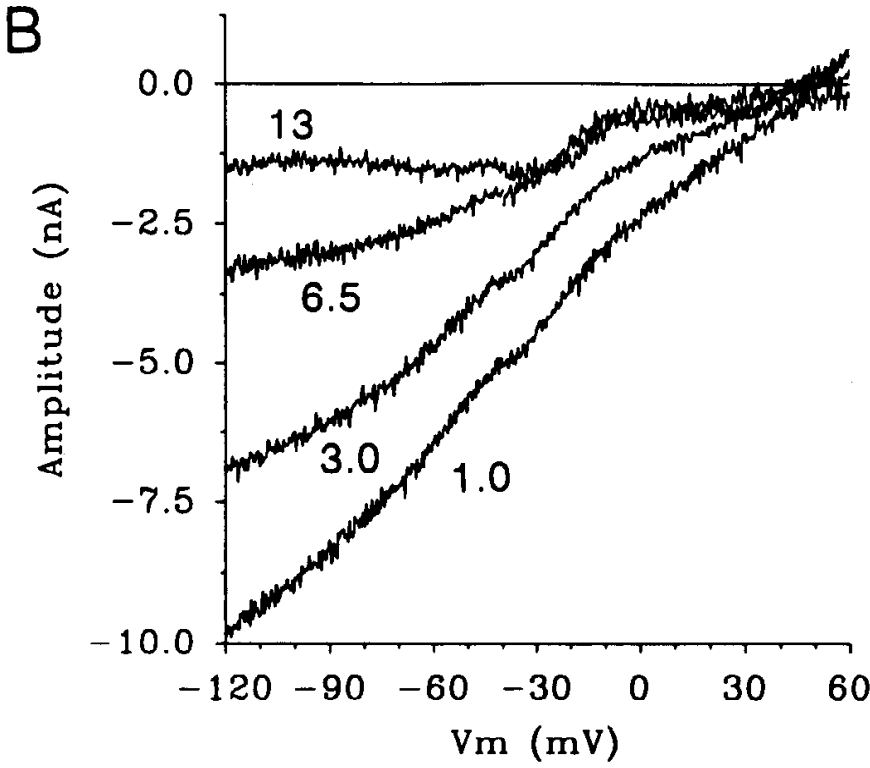

C

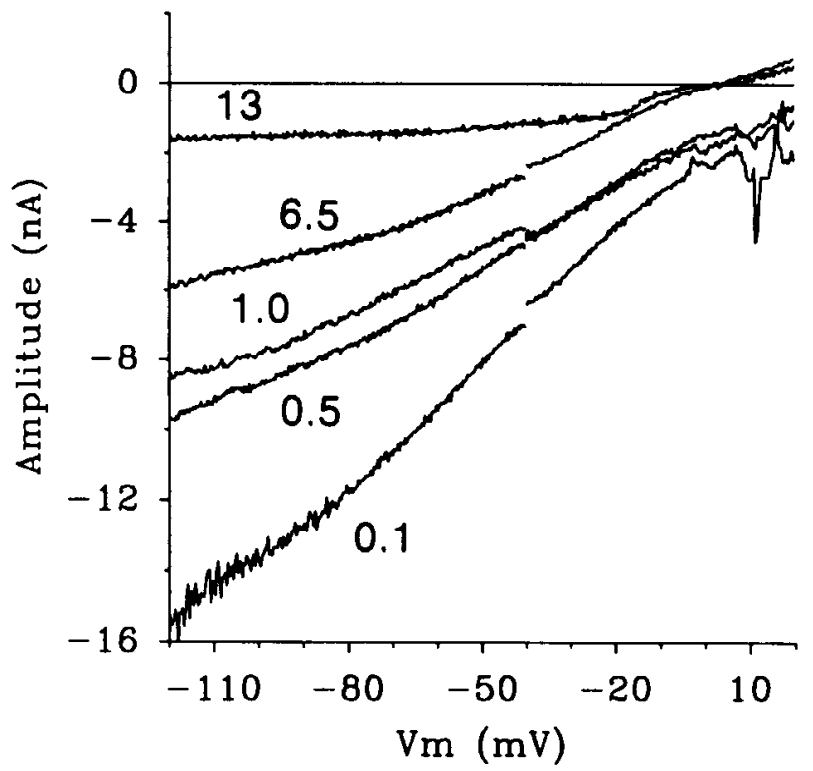

Figure 7. Effect of extracellular $\mathrm{Ca}^{2+}$ on the proctolin-evoked current: responses to proctolin measured with $\mathrm{KCl}$ electrodes in the presence of PTX, TTX, TEA, and $\mathrm{Cd}^{2+}$ at different concentrations of extracellular $\mathrm{Ca}^{2+} . V_{h}=-40 \mathrm{mV} . A$, Raw currents measured in $\left[\mathrm{Ca}^{2+}\right]_{\text {out }}$ indicated (in mM) to the left of each trace. The concentration of divalent cations was not compensated. $\mathbf{M g}^{2+}$ at 26 mm was always present. At the peak of the response, two voltage sawteeth were applied, separated by an interval of $5 \mathrm{sec}$ : from $V_{h}$ to $+60 \mathrm{mV}$ and back to $V_{h}$, and then from $V_{h}$ to -120 $\mathrm{mV}$ and back to $V_{h}($ rate $=250 \mathrm{mV} / \mathrm{sec})$. The first sawtooth was applied in the depolarizing direction to prevent the deinactivation of an A-like current that occurs with hyperpolarizations. $B$, Same cell as in $A$. The $I / V$ curves were constructed from the initial two halves of each sawtooth described in $A$ to avoid excessive contamination by currents activated at the extremes of each sawtooth. The $\left[\mathrm{Ca}^{2+}\right]_{\text {out }}$ is indicated (in mM) next to each trace. $C$, Same protocol as in $A$ but from a different cell. In this case, the divalent concentration was kept constant at $39 \mathrm{~mm}$ with added $\mathrm{Mg}^{2+}$. The $\left[\mathrm{Ca}^{2+}\right]_{\text {out }}$ is indicated (in $\mathrm{mM}$ ) next to each trace.

pendencies similar to that of the proctolin current are also predominantly carried by $\mathrm{Na}^{+}$(Aldenhoff et al., 1983; Kononenko et al., 1983; Haynes et al., 1986; Gillette and Green, 1987; Nakamura and Gold, 1987; Ichinose and McAdoo, 1988; Matsumoto et al., 1988; Kehoe, 1990) and appear to be mediated by cyclic nucleotide intracellular messengers (Aldenhoff et al., 1983; Kononenko et al., 1983; Connor and Hockberger, 1984; Haynes et al., 1986; Gillette and Green, 1987; Nakamura and Gold, 1987; Ichinose and McAdoo, 1988; Matsumoto et al., 1988; Kehoe, 1990).
Proctolin itself has been proposed to act via a cAMP-dependent mechanism (Jennings et al., 1983; Orchard et al., 1989; Bishop et al., 1991) and via a G-protein (Bittar and Nwoga, 1989 ) in other preparations. The slow nature of the proctolin response we have described (see Figs. 1, 2A) also suggests the mediation of a second messenger system, which, based on the existing evidence, may be a cyclic nucleotide or a G-protein.

The possibility remains that, as is the case for many agonistactivated currents, more than one type of proctolin-evoked current exist in our neurons, or that another voltage-activated cur- 
rent expressed by these cells is modulated by proctolin. The results we have shown were obtained in the presence of TTX, PTX, TEA, and $\mathrm{Cd}^{2+}$, any of which may mask an effect of the peptide on anothcr currcnt. In crayfish skcletal muscle, Bishop et al. (1991) showed that proctolin modulates the voltage-dependent activation of $\mathrm{Ca}^{2+}$ channels, effects that would have been masked by the $\mathrm{Cd}^{2+}$ we used. Finally, in barnacle muscle fibers proctolin activates a ouabain-insensitive $\mathrm{Na}^{+}$efflux (Bittar and Nwoga, 1989), an effect that would have been masked by the low $\mathrm{Na}^{+}$influx due to the presence of TTX in our preparations. However, although it is certainly possible that the proctolin target neurons display an additional proctolin response, we saw no indication that any of the pharmacological agents we used to isolate the proctolin current for study influenced the amplitude or the character of the proctolin response.

The voltage dependence of the proctolin-evoked current makes it ideally suited for its function as a modulator of the pyloric network. We have shown that proctolin can activate an inward current displaying strong outward rectification in its target cells. In normal saline, this current has a maximum amplitude near or at the resting potential of the cell (Table 1). $V_{\text {rest }}$ is also the point on the $I / V$ curve where the slope conductance is the lowest (90-100 nS; Golowasch, 1990). Therefore, at this $V_{m}$ a very small current can induce a depolarization of 10-20 mV (see Figs. 1, 2, 4A, 5A), which can activate action potentials as well as a host of other voltage-dependent currents (Golowasch and Marder, 1992).

When the pyloric system is rhythmically activated, all the component neurons, including the LP cell, undergo large input conductance changes, partly driven by synaptic activity and partly by the activation of voltage-dependent conductances (Eisen and Marder, 1982; Miller and Selverston, 1982; Russell and Hartline, 1982). Under those conditions, the maximum conductance change induced by proctolin (a maximum chord conductance of about $80 \mathrm{nS}$ at an $E_{\text {rev }}$ of near $0 \mathrm{mV}$ ) will be swamped by the high background conductance and the activation of the proctolin current will have a very small effect. Therefore, the proctolin-evoked current will have a stronger depolarizing effect the lower the background conductance of the cell. Thus, when the pyloric rhythm decreases in intensity and the rhythm slows down, the activation of a small inward current by proctolin will have a depolarizing effect on the LP cell that can make it cross the threshold for action potential generation. Conversely, when the rhythm is strongly active and high background conductances are present, one can expect the proctolin-evoked current to have only a minor effect on the activity of the LP neuron. This, therefore, can contribute to the state (activity)-dependent effect of proctolin (Nusbaum and Marder, 1989b). Interestingly, Hooper and Marder (1987) previously showed that circuit interactions play an important role in limiting the maximal frequency the pyloric network can produce in proctolin. The data presented here show that the ionic mechanisms underlying proctolin's actions will play a role in limiting the maximal excitation produced by proctolin. This suggests that cellular and circuit interactions are likely to act coordinately to produce a defined output from the pyloric network.

\section{References}

Aldenhoff JB, Hofmeier G, Lux HD, Swandulla D (1983) Stimulation of a sodium influx by cAMP in Helix neurons. Brain Res 276:289296.

Bishop CA, Krouse ME, Wine JJ (1991) Peptide cotransmitter po- tentiates calcium channel activity in crayfish skeletal muscle. J Neurosci 11:269-276.

Bittar E, Nwoga J (1989) Further observations on the behavior of ouabain-insensitive sodium efflux towards proctolin in barnacle muscle fibers. J Physiol (Lond) 419:435-453.

Connor JA, Hockberger P (1984) A novel membrane current induced by injection of cyclic nucleotides into gastropod neurones. J Physiol (Lond) 354:139-162.

Eisen JS, Marder E (1982) Mechanisms underlying pattern generation in lobster stomatogastric ganglion as determined by selective inactivation of identified neurons. III. Synaptic connections of electrically coupled pyloric neurons. J Neurophysiol 48:1392-1415.

Flamm RE, Harris-Warrick RM (1986) Aminergic modulation in the lobster stomatogastric ganglion. I. Effect on the motor pattern and activity of neurons within the pyloric circuit. J Neurophysiol 55:847865.

Freschi JE (1989) Proctolin activates a slow, voltage-dependent sodium current in motoneurons of the lobster cardiac ganglion. Neurosci Lett 106:188-192.

Gillette R, Green DJ (1987) Calcium dependence of voltage sensitivity in adenosine $3^{\prime}-5^{\prime}$-cyclic phosphate-stimulated sodium current in Pleurobrachaea. J Physiol (Lond) 393:233-245.

Golowasch J (1990) Characterization of a stomatogastric ganglion neuron. A biophysical and a mathematical description. $\mathrm{PhD}$ thesis, Brandeis University.

Golowasch J, Marder E (1992) Ionic currents of the lateral pyloric neuron of the stomatogastric ganglion of the crab. J Neurophysiol, in press.

Greenaway P (1985) Calcium balance and molting in the Crustacea. Biol Rev 60:425-454.

Haynes LW, Kay AR, Yau K-W (1986) Single cyclic GMP-activated channel activity in excised patches of rod outer segment membrane. Nature 321:66-70.

Heinzel HG, Selverston AI (1988) Gastric mill activity in the lobster. III. The effects of proctolin on the isolated central pattern generator. $\mathrm{J}$ Neurophysiol 59:565-585.

Hooper SL, Marder E (1987) Modulation of a central pattern generator by the peptide, proctolin. I Neurosci 7:2097-2112.

Hooper SL, O'Neil MB, Wagner R, Ewer J, Golowasch J, Marder E (1986) The innervation of the pyloric region of the crab, Cancer borealis: homologous muscles in decapod species are differently innervated. J Comp Physiol A 159:227-240.

Ichinose M, McAdoo DJ (1988) The voltage-dependent, slow inward current induced by the neuropeptide FMRFamide in Aplysia neuron R14. J Neurosci 8:3891-3900.

Jennings KR, Steele RW, Starratt AN (1983) Cyclic AMP actions on proctolin- and neurally-induced contractions of the cockroach hindgut. Comp Biochem Physiol 74C:69-74.

Kehoe J (1990) Cyclic AMP-induced slow inward current in depolarized neurons of Aplysia californica. J Neurosci 10:3194-3207.

Kononenko NI, Kostyuk PG, Shcherbatko D (1983) The effect of intracellular cAMP injections on stationary membrane conductance and voltage- and time-dependent ionic currents in identified snail neurons. Brain Res 268:321-338.

Marder E (1984) Mechanisms underlying neurotransmitter modulation of a neuronal circuit. Trends Neurosci 7:48-53.

Marder E (1987) Neurotransmitters and neuromodulators. In: The stomatogastric nervous system (Selverston AI, Moulins M, eds), pp 263-300. New York: Springer.

Marder E, Paupardin-Tritsch D (1978) The pharmacological properties of some crustacean neuronal acetylcholine, $\boldsymbol{\gamma}$-aminobutyric acid, and L-glutamate responses. J Physiol (Lond) 280:213-236.

Marder E, Hooper SL, Siwicki KK (1986) Modulatory action and distribution of the neuropeptide proctolin in the crustacean stomatogastric nervous system. J Comp Neurol 243:454-467.

Matsumoto M, Sasaki K, Sato M, Shozushima M, Takashima K (1988) Dopamine-induced depolarizing responses associated with negative slope conductance in LB-cluster neurones of Aplysia. J Physiol (Lond) 407:199-213.

Miller JP, Selverston AI (1982) Mechanisms underlying pattern generation in lobster stomatogastric ganglion as determined by selective inactivation of identified neurons. II. Network properties of pyloric system. J Neurophysiol 48:1416-1432.

Nakamura T, Gold GH (1987) A cyclic nucleotide-gated conductance in olfactory receptor cilia. Nature 325:442-444. 
Nowak L, Bregestovski P, Ascher P, Herbert A, Prochiantz A (1984) Magnesium gates glutamate-activated channels in mouse central neurones. Nature 307:462-465.

Nusbaum MP, Marder E (1989a) A modulatory proctolin-containing neuron (MPN). I. Identification and characterization. J Neurosci 9: 1591-1599.

Nusbaum MP, Marder E (1989b) A modulatory proctolin-containing neuron (MPN). II. State-dependent modulation of rhythmic motor activity. J Neurosci 9:1600-1607.
Orchard I, Belanger JH, Lange AB (1989) Proctolin: a review with emphasis on insects. J Neurobiol 20:470-496.

Russell DF, Hartline DK (1982) Slow active potentials and bursting motor patterns in pyloric network of the lobster, Panulirus interruptus. J Neurophysiol 48:914-937.

Selverston AI, Moulins M, eds (1987) The crustacean stomatogastric system. Berlin: Springer. 